UDC 327.83(470+571)

Submitted: 15.01 .2020

LBC 66.4(2Poc), 4

Accepted: 03.04.2020

\title{
ROLE OF THE CONTEMPORARY RUSSIAN UNIVERSITY IN PUBLIC DIPLOMACY (THE CASE OF VOLGOGRAD STATE UNIVERSITY)
}

\author{
Ekaterina V. Arkhipova \\ Volgograd State University, Volgograd, Russian Federation \\ Elena F. Parubochaya \\ Volgograd State University, Volgograd, Russian Federation \\ Constantinos Koliopoulos \\ Panteion University of Social and Political Sciences, Athens, Greece
}

\begin{abstract}
Introduction. The contemporary university in the conditions of globalization has enriched its traditional functions to educate and create new elites with attracting not only domestic students but also the foreign youth to the educational and research process. In some cases it can maintain public diplomacy held by the domestic government still influencing it via the requests made by research professionals. This influence may come through the collision of interests of both researchers with students and the government. A Russian university represents mainly the government, that's why it's important to discover its role in public diplomacy. Methods and materials. The neoliberal approach to J. Nye's concept of "soft power" gives the possibility to consider the university as a public institute enriching state's soft power through public diplomacy. Official speeches of Russian government representatives, publications of Russian researchers, university web-sites give the ground to understand the Russian approach to the methods of public diplomacy. Analysis. First of all, it's important to reveal the ways to interpret the word combination "public diplomacy" in Russian. There are several possible terms: "publichnaya", "obshchestvennaya", "narodnaya" diplomacy. The ways to use the word show different gradations of its meaning in research and political discourses which determine possible actors of public diplomacy in the Russian language. However, Russian officials in contrast to Russian researchers accept the term "obshchestvennaya" to describe the activity of government institutions in public diplomacy. That's why a university can be considered as an actor of "obshchestvennaya" diplomacy. Secondly, we reveal the ways to implement public diplomacy by Volgograd State University as one of regional universities. Results. Russian researchers following the English-language studies differentiate the concepts of "obshchestvennaya" and "publichnaya" (public) diplomacy according to the actors that implement this policy: the state cannot implement "obshchestvennaya" diplomacy, because it is a prerogative of social movements or non-governmental organizations (NGOs). At the same time, the concept of public diplomacy covers both the work of NGOs and the work of the state in creating its favorable image. However, Russian officials, trying to avoid the use of the Russian term "public diplomacy" incorrectly sounding in Russian, give preference to the phrase "obshchestvennaya diplomacy", implying that NGOs carry out public diplomacy with the help and on the initiative of the state. Moreover, they are not only public organizations who can conduct policies in this area. $\therefore$ In other words, officials suppose that in comparison with research discourse, the circle of participants in "obshchestvennaya" diplomacy enlarges at the expense of state funds and platforms. Thus, a university that implements educational, research and publishing projects is involved in "obshchestvennaya" diplomacy. The position of the university in society, the authority of specialists whom it manages to attract, their international activity provide the soft power of the state.

Key words: "soft power", "obshchestvennaya" diplomacy, public diplomacy, Russia, Volgograd State University, education.

Citation. Arkhipova E.V., Parubochaya E.F., Koliopoulos C. Role of the Contemporary Russian University in Public Diplomacy (The Case of Volgograd State University). Vestnik Volgogradskogo gosudarstvennogo universiteta. Seriya 4. Istoriya. Regionovedenie. Mezhdunarodnye otnosheniya [Science Journal of Volgograd State University. History. Area Studies. International Relations], 2020, vol. 25, no. 2, pp. 241-252. (in Russian). DOI:

(c) https://doi.org/10.15688/jvolsu4.2020.2.18
\end{abstract}




\title{
РОЛЬ СОВРЕМЕННОГО РОССИЙСКОГО УНИВЕРСИТЕТА В ОБЩЕСТВЕННОЙ ДИПЛОМАТИИ (НА ПРИМЕРЕ ВОЛГОГРАДСКОГО ГОСУДАРСТВЕННОГО УНИВЕРСИТЕТА)
}

\author{
Екатерина Владимировна Архипова \\ Волгоградский государственный университет, г. Волгоград, Российская Федерация \\ Елена Федоровна Парубочая \\ Волгоградский государственный университет, г. Волгоград, Российская Федерация \\ Константинос Колиопулос \\ Университет «Пантеон» социальных и политических наук, г. Афины, Греция
}

\begin{abstract}
Аннотация. Введение. Современный университет в условиях глобализации помимо своих традиционных функций по обучению и созданию новых элит для своего сообщества привлекает в образовательный и исследовательский процесс не только отечественных студентов, но и иностранную молодежь. В некоторых случаях он может поддерживать публичную дипломатию. Российский университет является частью государственного института, поэтому важно выяснить его роль в публичной дипломатии, понимание которой может существенно различаться среди исследователей и представителей власти. Meтоды. Неолиберальный подход к концепции «мягкой силы» Дж. Ная дает нам возможность рассматривать университет как государственно-общественный институг, обогащающий «мягкую силу» государства посредством публичной дипломатии. На основе выступлений представителей российского правительства и официальных лиц, исследований, проведенных российскими учеными-международниками и вебсайтов российских фондов, а также университетов составлено представление о наполнении российской общественной дипломатии и особенностях ее реализации в университетской среде. Анализ. Для описания нетрадиционной дипломатии в русском языке возможно использование нескольких синонимов: «публичная», «общественная», «народная» дипломатия. Во-первых, важно проанализировать способы толкования этих словосочетаний, которые показывают различные градации его значения в исследовательских и политических дискурсах и определяют возможных субъектов публичной дипломатии. Во-вторых, в статье необходимо раскрыть пуги реализации публичной дипломатии на примере работы Волгоградского государственного университета как типичного провинциального вуза, который можно рассматривать как актор, обеспечивающий «мягкую силу» государства. Результаты. В статье определена разница в интерпретации термина «общественная / публичная» дипломатия в российском научном и политическом дискурсах. Практики в сфере внешней политики и дипломатии, стараясь избегать употребления некорректно звучащего на русском языке термина «публичная дипломатия», отдают предпочтение словосочетанию «общественная дипломатия», подразумевая, что НПО осуществляют общественную дипломатию с помощью и по инициативе государства, более того, не только общественные организации могут проводить политику в этой сфере. Иными словами, по сравнению с научным дискурсом в публичной сфере круг участников общественной дипломатии расширяется за счет государственных фондов, площадок. Таким образом, университет, реализующий образовательные, исследовательские и издательские проекты, вовлечен в общественную дипломатию. Положение вуза в обществе, авторитет специалистов, которых ему удается привлечь, их международная активность обеспечивают «мягкую силу» государства. В ходе работы над статьей часть, посвященная анализу зарубежных представлений о публичной дипломатии, проанализирована К. Колиопулосом, российские представления о публичной и общественной дипломатии определены Е.В. Архиповой. Анализ работы вуза по направлению общественной дипломатии осуществлен Е.Ф. Парубочей.

Ключевые слова: «мягкая сила», общественная дипломатия, публичная дипломатия, Россия, Волгоградский государственный университет, образование.

Цитирование. Архипова Е. В., Парубочая Е. Ф., Колиопулос К. Роль современного российского университета в общественной дипломатии (на примере Волгоградского государственного университета) // Вестник Волгоградского государственного университета. Серия 4, История. Регионоведение. Международные отношения. - 2020. - Т. 25, № 2. - С. 241-252. - DOI: https://doi.org/10.15688/jvolsu4.2020.2.18
\end{abstract}


Введение. В настоящее время на современный российский университет возлагается не только роль просвещения и создания молодых кадров. Благодаря развитию процессов глобализации, появившейся возможности путешествовать высшее учебное заведение путем привлечения интернациональной молодежи к процессу обучения, ученых - к научным исследованиям становится проводником российской культуры и науки за рубежом. Деятельность российских вузов в сфере публичной дипломатии уже привлекала внимание российских исследователей. Образование как инструмент «мягкой силы» рассматривается в работах А.В. Торкунова, М.М. Лебедевой $[16 ; 21]$. Теоретические аспекты роли образования раскрываются в статье А.В. Григоряна и А.А. Габриэляна [1]. Е.П. Панова определила роль получения высшего образования иностранными студентами в установлении долгосрочных связей [12]. А.Е. Фоминых проанализировал роль российских университетов в продвижении информационно-культурного влияния в странах Центральной Азии [22].

При этом исследователи определяют высшие учебные заведения исключительно как проводники государственной политики и перечисляют программы сотрудничества, которые вузы проводят за рубежом. Такой подход ограничивает географию реализации публичной дипломатии, оставляя без внимания те возможности, которые открываются перед вузом на «своей» территории.

Волгоградский государственный университет гораздо моложе классических университетов соседних областей. Он был основан в 1980 году. При этом в настоящее время он занимает прочные позиции в национальных и зарубежных рейтингах, например, таких как «ТОП-100 лучших вузов по версии «Эксперт РА»», «Национальный рейтинг университетов "Интерфакс"», QS, THE University Impact Rankings; вуз привлекает большое количество студентов, как среди российских граждан, так и иностранных, и является средоточием квалифицированных специалистов, вовлеченных в международные исследования. С 2014 г. ВолГУ является одним из соучредителей «Международного форума общественной дипломатии», который проходит в Волгограде. Уже в 2015 г. между администрацией г. Волгограда и руководством ВолГУ было подписано соглашение о создании ресурсного Центра общественной дипломатии. Таким образом, вуз предоставил площадку для организации общественной дипломатии в г. Волгограде, обеспечив ее и кадровой поддержкой из числа своих сотрудников. В связи с этим представляется важным осмыслить роль вуза как актора общественной дипломатии: является ли он только площадкой для ее реализации или сам может выступать инициатором в этой сфере. Деятельность вузов в научном и политическом дискурсе ранее связывали с культурной политикой страны или с ее «культурной дипломатией». Также мог использоваться термин «народная дипломатия». Однако сейчас при описании подобной работы можно столкнуться с понятиями «общественная дипломатия» и «публичная дипломатия». Для определения роли вуза необходимо разобраться в терминологии.

Примечательно, что в англоязычных исследованиях авторы указывают на главенствующую роль государства в ходе реализации «публичной дипломатии». В русскоязычных исследованиях термины «общественная» и «публичная дипломатия» использовались как синонимичные, а со временем их стали разделять; в российском публичном дискурсе понятия зачастую смешиваются, а иногда используются и более узкие термины («культурная», «народная») [8].

В современных научном и политическом дискурсах понятие «public diplomacy» так или иначе связывается с именем Дж. Ная, который в 1980-х гг. ввел термин «мягкая сила». Сосредоточившись на использовании неполитических методов ведения внешней политики, исследователь указывал, что культурная и публичная дипломатии являются важным элементом «мягкой силы» [27]. При этом, как показывает сравнительный анализ, проведенный Е.Ф. Парубочей и Н.В. Пискуновым, общественная дипломатия имеет схожие функции с «мягкой силой», являясь «инструментом исполнения основных задач “мягкой силы” государства» [13, с. 199].

Методы и материалы. Говоря о соотношении «жесткой» и «мягкой силы», Дж. Най возводит последнюю к идее привлекательности в отличие от «жесткой», для которой спе- 
цифична пропаганда для создания собственного имиджа. Такой подход говорит о неолиберальной природе концепции «мягкой силы». В связи с этим авторы настоящей работы исходят из неолиберального подхода, позволяющего рассматривать вузы как государственно-общественные институты, оказывающие влияние на общественную сферу дипломатической деятельности, но не занимающиеся активной пропагандой. Двойственность положения вузов в российском образовательном пространстве обусловлена тем, что, будучи сосредоточием профессионалов в научной сфеpe, имеющих интересы по реализации международных проектов, университет все же является частью государственной системы и ограничивает или направляет международные контакты своих сотрудников. В связи с этим важно применить структурно-функциональный анализ для определения функционального назначения такого института общественной дипломатии, как вуз.

На основе выступлений представителей российского правительства и официальных лиц, исследований, проведенных российскими учеными-международниками и материалов веб-сайтов российских фондов, а также университетов составлено представление о наполнении российской общественной дипломатии и особенностях ее реализации в университетской среде.

Анализ. Внешняя политика в области культуры стала одним из направлений дипломатической деятельности ряда европейских стран еще с конца XIX века. Основным ее содержанием на протяжении многих лет оставались образовательные проекты, цель которых заключалась в формировании положительного образа страны и в усилении собственного влияния на граждан других стран. С этой целью, например, Франция и Германия уже на рубеже XIX-XX вв. открывали свои школы в странах Ближнего Востока, Юго-Восточной Азии.

Как заверяют А.И. Кубышкин и Н.А. Цветкова в своей работе «Публичная дипломатия США», к периоду Второй мировой войны «США превратились в лидирующую державу по масштабам культурной дипломатии» [6, c. 6], суть которой сводилась к проведению внешней политики в области культуры, обра- зования и информации. В терминологии Дж. Ная это представляет основу «мягкой силы» государства, и ее инициатором выступает не общество, а именно государство.

Необходимо также отметить и то, как европейские страны старались внедрить достижения в области публичной или общественной дипломатии. Между Францией и ФРГ в 1963 г. был подписан Елисейский договор о примирении и дружбе, который предполагал взаимные стажировки военных, обменные поездки для студенчества, изучение языка, стимулирование сотрудничества в сфере научных исследований. Этими программами главы государств открыли коридор возможностей для общения между молодыми поколениями стран, которые не так давно воевали друг с другом. Примечательно, что договор признавал, что «решающая роль [молодежи] состоит в укреплении немецко-французской дружбы» [29]. Именно общение студенчества стало стартовой точкой улучшения взаимоотношений [25, p. 131]. При этом в документах данная политика связывалась пока с культурным сотрудничеством, инициируемым и осуществляемым государством.

В русском языке путаницу в использовании терминов можно объяснить: во-первых, тем, что у самого словосочетания, пришедшего из английского языка (public diplomacy), может быть несколько переводов; во-вторых, тем, что в русском языке уже сложилась практика использования понятия «народная дипломатия» при определении общественной сферы дипломатической деятельности. Так, еще в СССР использовали термин «народная дипломатия» (people-to-people diplomacy) для определения политики, целевой аудиторией которой считались иностранные граждане невысокого происхождения, неправительственные объединения, которые в перспективе должны были перехватить влияние у действующей элиты. Надо отметить, в целом наполнение этой идеи существенно не отличалось от понятия «культурная дипломатия» и предполагало образовательные проекты, которые представляют собой ядро этой политики [9]. В связи с этим российскими официальными лицами термины «культурная» и «народная» дипломатия по-прежнему употребляются для описания одного явления. 
Относительно новые для русскоязычных исследований и публичного дискурса термины «общественная» или «публичная дипломатия» являются вариантами перевода словосочетания public diplomacy, введенного в научный оборот в середине 1960-х гг. деканом школы права и дипломатии им. Флетчера университета Тафтса Э. Галлионом, который, констатируя происходящие процессы, определил их как политику, включающую в себя «программы, финансируемые правительством, направленные на информирование и оказание воздействия на общественное мнение в других странах» $[28$, p. 6]. И образовательные проекты в этой политике занимали лидирующее место.

Таким образом, на протяжении XX в. уже сложилась практика применения того, что Дж. Най в конце века назвал «мягкая сила», посредством реализации программ культурной / народной дипломатии. Отметим, что по существу государство выступает источником проведения и культурной, и народной дипломатии. При этом уже введенный в научный оборот термин «публичная дипломатия» еще не находит активного применения.

Распад социалистического блока, а за ним и Советского Союза привел к существенному расширению мировых практик по наполнению публичной дипломатии включением в нее таких направлений, как развитие рыночной экономики, предоставления кредитов; влияние на политическую элиту, создание НКО, выделение грантов на общественную и политическую активность; развитие независимых от государства СМИ. Существенное увеличение набора программ, входящих в основу публичной дипломатии, подводит к уточнению того, что «культурная» или «народная» дипломатия уже не являются синонимами понятию «публичная» дипломатия, а становятся ее частью.

Спад интереса к публичной дипломатии в 1990-х гг. был преодолен после событий 2001 г., когда появились новые исследования в области «публичной дипломатии» и политики разных стран вновь стали инициировать программы в этой сфере [2; 24, p. XIX]. Неизменным составным элементом по-прежнему оставались программы образовательных обменов [17]. В это же время интерес к публич- ной дипломатии и ее направлениям стал проявляться и в российских исследованиях.

Российский политолог И.Л. Шершнев разделяет понятия «общественная» и «народная дипломатия», отмечая, что последний термин использовался в советское время, когда дипломатия осуществлялась от имени народа, то есть заявлялась народная дипломатия. В то же время современная общественная дипломатия гораздо шире и осуществляется от имени гражданского общества и самим гражданским обществом. Задачи общественной дипломатии - продвижение национальных интересов и их отстаивание [24, p. 165]. Таким образом, исследователь определял главного актора общественной дипломатии - общество.

Четкую дефиницию «публичная дипломатия» вслед за А.В. Долинским [3] используют авторы научного издания под редакцией M.М. Лебедевой, где публичная дипломатия описана как политика воздействия одного государства на общество другого в политических целях. Все же и здесь редактор признает, что достаточно сложно было согласовать понимание этого термина авторами частей книги [14].

Это значит, что для исследователей «публичная дипломатия» представляется шире, включает в себя не только культурную но и общественную дипломатию, экономическую политику. Отличаются термины и по акторам: для общественной дипломатии общество является источником и ресурсом инициативы, а для публичной - государство. В то же время термин «народная» дипломатия признается устаревшим, так как возникают сомнения в правосубъектности самого «народа».

Немного иную терминологию предпочитают использовать представители власти в РФ. Проиллюстрируем это на примере эволюции законодательства в сфере публичной / общественной дипломатии, которое начинает складываться с 2004-2005 годах. Если в Концепции внешней политики РФ 2008 г. по одному разу используются оба термина [5], то уже в Концепции внешней политики 2016 г. в пп. «Л》 п. 45 закреплено: «Россия... видит свои задачи в том, чтобы развивать, в том числе с использованием ресурса общественной дипломатии, международное культурное и гуманитарное сотрудничество...» [4]. 
Интересно отметить, что российский министр иностранных дел С.В. Лавров говорит о «народной дипломатии», отмечая, что ее цель состоит «в деле продвижения положительной, объединительной, устремленной в будущее государственной повестки дня во взаимоотношениях стран» [7]. Очевидно, что министр подразумевает общественную / публичную дипломатию, а присутствие на научно-практической конференции «Народная дипломатия. Партнерства общественных организаций» обязывает к применению устаревшего термина «народная».

В 2010 г. состоялся международный общественный форум «Роль народной дипломатии в развитии международного гуманитарного сотрудничества» [10]. Чрезвычайный и Полномочный Посол Российской Федерации в Республике Молдова Ф. Мухаметшин выступил в качестве одного из организаторов форума и дал такое определение: «общественная дипломатия - коммуникация с зарубежной общественностью силами государственных и негосударственных игроков с целью косвенного влияния на общественное мнение и процессы принятия внешнеполитических решений в стране-партнере. При этом следует также понимать, что общественная дипломатия не заменяет, да и не может заменить усилий государства, но является органичным дополнением, продолжением внешнеполитического курса страны» [8]. То есть, для дипломата главным представляется не источник действий, а сам процесс коммуникации, хотя акторами могут быть как государственные, так и негосударственные институты. Однако такое определение, где целью заявлено «косвенное влияние» уже идет вразрез с определением «мягкой силы», в котором Дж. Най уточняет, что пропаганда наносит существенный вред имиджу государства.

По итогам этого форума в свет вышел сборник «Современная общественная дипломатия: российское измерение», в который вошли размышления участников форума о терминологии, истории развития общественной дипломатии в России, о возможностях и перспективах общественной дипломатии России [18].

Свободное использование терминов и смешение их значений можно наблюдать и в работе общественных институтов. Так, на сайте Россотрудничества при описании одной из своих сфер деятельности «Общественная дипломатия» используется понятие «народная дипломатия» [11].

Таким образом, государственные служащие очевидно предпочитают термин «общественная дипломатия», который звучит не так некрасиво, как «публичная дипломатия» и который, в отличие от определения, данного российским исследователями выше, предполагает участие государства в коммуникации между общественными силами разных государств. При этом культурная дипломатия становится ее частью. В то же время устаревший термин «народная» дипломатия не вышел из употребления.

Исходя из сказанного, становится ясно, что деятельность вузов можно рассматривать как часть общественной дипломатии, которая для исследователей предстает частью публичной дипломатии, а для российских политиков и чиновников - ее синонимом.

Как считает Г. Мэлоун, «прежде чем представлять свое общество и его политику, вы должны хорошо узнать культуру, историю, психологию и, что немаловажно, особенности менталитета и языка народа, с которым вы планируете налаживать связи» [26, p. 12]. Таким образом, можно отметить, что современный вуз - это не только актор общественной дипломатии, но и кузница кадров для еe реализации. Примечательно, что американский советолог, дипломат $\mathrm{X}$. Тач в своей работе так определил требования к тому, кто может осуществлять мероприятия в рамках общественной дипломатии: 1) необходимо фундаментальное знание истории, институтов и культуры своей страны; 2) знать цель и содержание представляемой политики; 3) понимать народ страны, в которой осуществляется эта деятельность (их традиции, культуру и психологию); 4) быть компетентными собеседниками, имеющими представление о способах донесения информации [30, p. 39]. Подобные навыки могут быть воспитаны только или преимущественно в университетской среде. Вуз по заказу государства может осуществлять подготовку таких кадров, но ведь такой заказ может и не поступить и вуз с этим заказом может не справиться, если не сможет подобрать авторитетных специалистов в своей 
области. Здесь важно то, что присутствие исследователей, вовлеченных в международное сотрудничество, сама вузовская атмосфера создают благоприятную почву для развития общественной дипломатии и формирования квалифицированных специалистов, способных ее осуществлять.

В России уже сформировался ряд вузов, которые занимаются подготовкой специалистов в области международных отношений и общественной дипломатии. Конечно же, надо отметить вузы, которые создавались как центры образования зарубежной элиты (РУДН, МГИМО, МГЛУ). Но в основном такие вузы сосредоточены в Москве и Санкт-Петербурге, что обусловлено исторически сложившейся материально-технической базой, направлением распределения ресурсов. Однако в 1990-х гг. в РФ в региональных вузах помимо традиционной лингвистической подготовки стали открываться специальности (как, например, «регионоведение»), выпускники которых могли уверенно выполнять функции в сфере общественной дипломатии, международных отношений, что особенно было востребовано в приграничных областях. В их числе были Волгоградский государственный университет, Саратовский государственный университет, Воронежский государственный университет, Ростовский государственный университет.

Помимо подготовки кадров для этой сферы, сами вузы способны привлекать студентов из других стран, что, как уже признано, формирует позитивное отношение будущей элиты к стране, предоставившей образование. Конечно, еще с советской эпохи сложилась практика привлечения студентов в медицинские вузы. Тем не менее необходимо понимать узость профессионального слоя, получившего советское, а затем и российское медицинское образование. В этом смысле классические университеты, предлагающие иностранным студентам специальности в разных отраслях знаний, закладывают основу «пророссийского» мышления в разнообразных профессиональных группах. Например, Волгоградский государственный университет привлекает иностранных абитуриентов практически по всем направлениям подготовки, если обучение на них не ограничено законодательными актами РФ. Финансирование образования осу- ществляется либо за счет бюджетных ассигнований федерального бюджета, если они направлены Министерством образования, либо за счет средств физических и юридических лиц [14]. Количество привлекаемых иностранных студентов в классических вузах ежегодно растет [15].

Современный вуз располагает и другими инструментами реализации общественной дипломатии, которые могут быть связаны с осуществлением учебного и научного сотрудничества. ВолГУ заключил более 50 соглашений о партнерстве с зарубежными вузами, согласно которым происходят академические обмены студентами и проводятся научные мероприятия преподавателями. К концу 2019 г. подписаны и действуют 53 соглашения с зарубежными вузами, 6 соглашений о кредитной мобильности в рамках программы Европейского Союза «Erasmus+». Вузом проводятся летние школы русского языка. Постоянство всех проектов и их успех связан с вкладом сотрудников вуза, которые помимо основной работы, заинтересованы в международном сотрудничестве, могут найти иностранных партнеров, знакомы с правилами организации международных проектов.

Российские политологи О.В. Столетов и И.А. Чихарев, размышляя на тему вклада университетов в развитие публичной дипломатии, указывают на большую роль издательств, функционирующих при университетах. Называя это «дискурсивным ресурсом университетов», исследователи отмечают, что издательства: 1) знакомят научный мир с достижениями исследователей своих вузов; 2) предпринимают усилия по включению периодических изданий вуза в международные базы данных и в дальнейшем поддерживают их индексацию в рейтингах цитирований; 3) создают благоприятный имидж самого вуза и страны, которую представляет журнал; 4) привлекают новые научные кадры из-за рубежа к краткосрочному и долгосрочному сотрудничеству [20]. Одной из целей государственного проекта «5-100», озвученного в 2012 г., было расширение участия российских университетов в международной образовательной и научной среде. Для этого предполагалось повышение международного индекса цитирования научных статей. В качестве способа дости- 
жения этой цели можно назвать включение уже существующих изданий в международные базы данных, что в свою очередь повышает престиж журнала и вуза и позволяет привлечь читателей и авторов не только в России, но и за рубежом. Волгоградский государственный университет также поддерживает 9 периодических изданий, которые включены в российские и зарубежные системы цитирования. Нельзя не отметить тот факт, что включение любого журнала в значимые международные базы является результатом усилий коллектива научных сотрудников.

Будучи частью системы образования, выполняющей государственный заказ, вуз не может выступить общественной организацией, которая выполняет функции общественной дипломатии. Примечательно, что согласно принятым положениям деятельность созданных правительством РФ организаций по поддержке общественной дипломатии [Российский совет по международным делам (РСМД) (2010 г.), фонд поддержки публичной дипломатии им. А.М. Горчакова (2010 г.)] направлена на финансирование именно негосударственных организаций, осуществляющих деятельность в сфере общественной дипломатии [19]. Таким образом, самими государственными институтами, созданными для поддержки общественной дипломатии, вузы исключены из программ государственного финансирования.

Сконцентрировать ресурсные условия для обеспечения общественной дипломатии удалось при создании Центра общественной дипломатии на базе ВолГУ в 2015 г. [23]. За 2015-2019 гг. силами Центра и благодаря поддержке руководства вуза удалось принять участие в организации 5 международных форумов «Диалог на Волге: мир и взаимопонимание в XXI веке»; организовать и провести 7 международных научно-практических конференций и семинаров, а также тематические лекции и семинары с иностранными участниками, реализовать зарубежные стажировки студентов вуза. География партнеров Центра охватывает Западное и Восточное полушарие: от США и Чили до Японии. Активная деятельность Центра, конечно же, опирается и на уже ставшие традиционными для Волгограда связи по линии городов-побратимов, поддержан- ные администрацией г. Волгограда [19]. Установление личных контактов сотрудниками вуза, поддержка на уровне руководства вуза и города создают условия для реализации общественной дипломатии в Волгограде. Однако существующие проблемы финансирования во многом можно связать с тем, что Центр действует на базе вуза и не может претендовать на государственную поддержку основных грантодателей в сфере общественной дипломатии.

Результаты. В научном дискурсе в России понятия «общественная» и «публичная» дипломатия отличаются акторами, осуществляющими эту политику: государство не может реализовывать общественную дипломатию, так как это прерогатива общественных движений или неправительственных организаций (далее - НПО). В то же время понятие «публичная дипломатия» охватывает как работу НПО, так и работу государства по созданию благоприятного имиджа. При этом практики в сфере внешней политики и дипломатии, стараясь избегать употребления некорректно звучащего на русском языке термина «публичная дипломатия», отдают предпочтение как раз словосочетанию «общественная дипломатия», подразумевая, что НПО осуществляют общественную дипломатию с помощью и по инициативе государства, более того, не только общественные организации могут проводить политику в этой сфере. Иными словами, по сравнению с научным дискурсом в публичной сфере круг участников общественной дипломатии расширяется за счет государственных фондов, площадок. При этом финансовую поддержку государство осуществляет только неправительственным организациям, работающим в сфере общественной дипломатии. Университет, реализующий образовательные, исследовательские и издательские функции, вовлечен в общественную дипломатию. Благодаря созданию специализированного центра вуз создает площадку, условия для реализации общественной дипломатии. Кроме того, положение вуза в обществе, авторитет специалистов, которых ему удается привлечь, их международная активность говорят о том, что вуз может выступать инициатором при реализации «мягкой силы» государства. 


\section{СПИСОК ЛИТЕРАТУРЫ}

1. Григорян, А. В. Высшее образование в контексте «мягкой силы» в системе международных отношений / А. В. Григорян, А. А. Габриэлян // Ученые записки ЗабГУ. - 2016. - Т. 11, № 2. - С. 14-23.

2. Долинский, А. Дискурс о публичной дипломатии / А. В. Долинский // Международные процессы. - 2011. - Т. 9, № 1 (25). - С. 63-73.

3. Долинский, А. Что такое общественная дипломатия и зачем она нужна России? / А. В. Долинский // Российский совет по международным делам. 2012. - Электрон. текстовые дан. - Режим доступа: http://russiancouncil.ru/analytics-and-comments/ analytics/chto-takoe-obshchestvennaya-diplomatiya-izachem-ona-nuzhna- (дата обращения: 02.01.2020).

4. Концепция внешней политики Российской Федерации (утв. Указом Президента РФ от 30 ноября 2016 г. № 640). - Доступ из информ.-правового портала «Гарант.ру».

5. Концепция внешней политики Российской Федерации, 15 июля 2008 г. // Президент России. Электрон. текстовые дан. - Режим доступа: http:// www.kremlin.ru/acts/news/785 (дата обращения: 10.01.2020).

6. Кубышкин, А. И. Публичная дипломатия США : учеб. пособие для вузов / А. И. Кубышкин, Н. А. Цветкова. - М. : Аспект Пресс, 2013. - 271 с.

7. Лавров подчеркнул значение народной дипломатии во взаимоотношениях стран // ИА REGNUM. 13.02.2018. - Электрон. текстовые дан. Режим доступа: https://regnum.ru/news/polit/ 2379693.html (дата обращения: 21.12.2019).

8. Мартыненко, Е. В. Народная (общественная) дипломатия в контексте современного международного общения / Е. В. Мартыненко, В. В. Матвиенко // Вестник РУДН. Серия: Международные отношения. - 2012. - № 1. - С. 57-60.

9. Можаева, Л. А. Всемирные фестивали молодежи и студентов как фактор общественной дипломатии в борьбе за укрепление мира / Л. А. Можаева // Вестник Российского государственного гуманитарного университета. - 2015. - № 13. - С. 145-159.

10. Мухаметшин, Ф. Открыть Россию для мира и мир для России / Ф. М. Мухаметшин // Международная жизнь. - 2011. - № 10. - Электрон. текстовые дан. - Режим доступа: https://interaffairs.ru/ jauthor/material/552 (дата обращения: 16.12.2019).

11. Общественная дипломатия // Россотрудничество. - Электрон. текстовые дан. - Режим доступа: http://rs.gov.ru/ru/activities/4 (дата обращения: 09.01.2020).

12. Панова, Е. П. Высшее образование как потенциал мягкой власти государства / Е. П. Панова // Вестник МГИМО-Университета. - 2011. - № 2 (16). C. 157-161.
13. Парубочая, Е. Ф. Общественная дипломатия как инструмент реализации российской «мягкой силы» / Е. Ф. Парубочая, Н. В. Пискунов // Вестник Волгоградского государственного университета. Серия 4, История. Регионоведение. Международные отношения. - 2018. - Т. 23, № 6. - С. 197-207. DOI: https://doi.org/10.15688/jvolsu4.2018.6.16.

14. Правила приема во ФГАОУ ВО «Волгоградский государственный университет» на образовательные программы бакалавриата, специалитета, магистратуры в 2020 г. (30.09.2019) // Институт международного образования (ИМО). - Электрон. текстовые дан. - Режим доступа: https://volsu.ru/ Abitur/pravila-priema.php (дата обращения: 10.01.2020).

15. Приказы о зачислении в 2019 году // Волгоградский государственный университет. - Электpoн. текстовые дан. - Режим доступа: https:// volsu.ru/Abitur/bachelor/prikazy-o-zachislenii-v-2019godu.php (дата обращения: 02.01.2020).

16. Публичная дипломатия: Теория и практика : науч. изд. / под ред. М. М. Лебедевой. - М. : Аспект Пресс, 2017. - 272 с.

17. Сазанова, Н. В. Советско-американские отношения в области культуры и науки в военный и послевоенный период / Н. В. Сазанова // Вестник Волгоградского государственного университета. Серия 4, История. Регионоведение. Международные отношения. - 2013. - № 1(23). - С. 69-74. DOI: http://dx.doi.org/10.15688/jvolsu4.2013.1.10.

18. Современная общественная дипломатия: российское измерение / под общ. ред. Ф. М. Мухаметшина. - М. : Белый город, 2011. - 240 с.

19. Сорокина, Д. А. Основные этапы развития публичной дипломатии в России / Д. А. Сорокина // Власть. - 2016. - № 4. - С. 132-137.

20. Столетов, О. В. Университеты как субъекты публичной дипломатии / О. В. Столетов, И. А. Чихарев // Геополитический журнал. - 2013. - № 2. C. $65-78$.

21. Торкунов, А. В. Образование как инструмент «мягкой силы» во внешней политике России / А. В. Торкунов // Вестник МГИМО (У). - 2012. № 4. - C. $86-89$.

22. Фоминых, А. Е. Российские университеты на образовательных рынках Центральной Азии: публичная дипломатия, сотрудничество и конкуренция / А. Е. Фоминых // Вестник Томского государственного университета. История. - 2014. - № 6 (32). C. $28-31$.

23. Центр общественной дипломатии. Волгоградский государственный университет. - Электрон. текстовые дан. - Режим доступа: http://cod.volsu.ru/ (дата обращения: 03.01.2020).

24. Шершнев, И. Л. Концептуальные основы проекта Федерального Закона «Об общественной 
дипломатии Российской Федерации» / И. Л. Шершнев // Вестник МГЛУ. - 2010. - Вып. 25 (604). C. $164-170$.

25. Le traité de l'Élysée et les relations francoallemandes 1945-1963-2003/ C. Defrance, U. Pfeil (éd.).Paris : CNRS éditions, 2005. -268 p.

26. Malone, G. Political Advocacy and Cultural Communications: Organising the Nation's Public Diplomacy / G. Malone. - Lanheim : University of America, 1988. - 178 p.

27. Nye, J. Soft Power and Higher Education. 2004 / J. Nye. - Electronic text data. - Mode of access: https:/ /www.academia.edu/10134073/Soft_power_university (accessed 24.12.2019).

28. The New Public Diplomacy. Soft Power in International Relations / ed. by J. Melissem. - London : Palgrave Macmillan, 2005. - 222 p.

29. Traité de l' Élysée (22 janvier 1963) // Le couple franco-allemand. - Electronic text data. - Mode of access: https://www.france-allemagne.fr/Traite-de-1-Elysee-22janvier-1963.html (дата обращения: 12.12.2019).

30. Tuch, H. N. Communication with the World. US Public Diplomacy Overseas / H. N. Tuch. - Washington : Georgetown University Press, 1990.-224p.

\section{REFERENCES}

1. Grigoryan A.V. Vysshee obrazovanie v kontekste «myagkoy sily» v sisteme mezhdunarodnykh otnosheniy [Higher Education in the Context of "Soft Power" Approach in the System of International Relations]. Uchenye zapiski ZabGU [Scholarly Notes of Transbaikal State University], 2016, vol. 11, no. 2, pp. 14-23.

2. Dolinskiy A. Diskurs o publichnoy diplomatii [Discourse on Public Diplomacy]. Mezhdunarodnye protsessy [International Trends], 2011, vol. 9, no. 1 (25), pp. 63-73.

3. Dolinskiy A. Chto takoe obshchestvennaya diplomatiya i zachem ona nuzhna Rossii? [What Is Public Diplomacy and Why Does Russia Need It?]. Rossiyskiy sovet po mezhdunarodnym delam [Russian Council on Foreign Affairs], 2012. URL: http:// russiancouncil.ru/analytics-and-comments/analytics/ chto-takoe-obshchestvennaya-diplomatiya-i-zachemona-nuzhna-/ (accessed 2 January 2020).

4. Kontseptsiya vneshney politiki Rossiyskoy Federatsii (utv. Ukazom Prezidenta RF ot 30 noyabrya 2016 g. № 640) [Concept of Russian Foreign Policy (Adopted by the Decree of the President of the Russian Federation Dated 30 November 2016 no. 640)]. Access from "Garant" informational and legal web portal.

5. Kontseptsiya vneshney politiki Rossiyskoy Federatsii, 15 iyulya 2008 g. [Concept of Russian Foreign Policy, July 15, 2008]. President Rossii
[President of Russia]. URL: http://www.kremlin.ru/acts/ news/785 (accessed 10 January 2020).

6. Kubyshkin A.I., Tsvetkova N.A. Publichnaya diplomatiya SShA: ucheb. posobie dlya vuzov [USA Public Diplomacy. Study Guide for Universities]. Moscow, Aspekt Press Publ., 2013. 271 p.

7. Lavrov podcherknul znachenie narodnoy diplomatii vo vzaimootnosheniyakh stran [Lavrov Stressed the Importance of Public Diplomacy in Relations Between Countries]. IA Regnum, February 13, 2018. URL: https://regnum.ru/news/polit/ 2379693.html (accessed 21 December 2019).

8. Martynenko E.V., Matvienko V.V. Narodnaya (obshchestvennaya) diplomatiya $\mathrm{v}$ kontekste sovremennogo mezhdunarodnogo obshcheniya [National (Public) Diplomacy in the Context of Modern International Communication]. Vestnik RUDN. Seriya: Mezhdunarodnye otnosheniya [Vestnik RUDN. International Relations], 2012, no. 1, pp. 57-60.

9. Mozhaeva L.A. Vsemirnye festivali molodezhi i studentov kak faktor obshchestvennoy diplomatii v borbe za ukreplenie mira [World Festivals of Youth and Students as a Factor in Public Diplomacy in the Struggle for Peace]. Vestnik Rossiyskogo gosudarstvennogo gumanitarnogo universiteta [Vestnik RGGU], 2015, no. 13, pp. 145-159.

10. Mukhametshin F. Otkryt Rossiyu dlya mira i mir dlya Rossii [Open Russia to the World and the World for Russia]. Mezhdunarodnaya zhizn [The International Affairs], 2011, no. 10. URL: https:// interaffairs.ru/jauthor/material/552 (accessed 16 December 2019).

11. Obshchestvennaya diplomatiya [Public Diplomacy]. Rossotrudnichestvo. URL: http:// rs.gov.ru/ru/activities/4 (accessed 9 January 2020).

12. Panova E.P. Vysshee obrazovanie kak potentsial myagkoy vlasti gosudarstva [Higher Education as a Potential of Soft Power of a State]. Vestnik MGIMO-Universiteta [MGIMO Review of International Relations], 2011, no. 2 (16), pp.157-161.

13. Parubochaya E.F., Piskunov N.V. Obshchestvennaya diplomatiya kak instrument realizatsii rossiyskoy «myagkoy sily» [Public Diplomacy as a Tool of the Russian Soft Power Implementation]. Vestnik Volgogradskogo gosudarstvennogo universiteta. Seriya 4, Istoriya. Regionovedenie. Mezhdunarodnye otnosheniya [Science Journal of Volgograd State University. History. Area Studies. International Relations], 2018, vol. 23, no. 6, pp. 197 207. DOI: https://doi.org/10.15688/jvolsu4.2018.6.16.

14. Pravila priema vo FGAOUVO «Volgogradskiy gosudarstvennyy universitet» na obrazovatelnye programmy bakalavriata, spetsialiteta, magistratury $\mathrm{V}$ 2020 g. (30.09.2019) [Admission Rules of Volgograd State University for Bachelor, Specialty, Master's Educational Programs in 2020 (September 30, 2019)]. Institut mezhdunarodnogo obrazovaniya (IMO) [Institute of 
International Education]. URL: https://volsu.ru/Abitur/ pravila-priema.php (accessed 10 January 2020).

15. Prikazy o zachislenii v 2019 godu [Orders for Admission in 2019]. Volgogradskiy gosudarstvennyy universitet [Volgograd State University]. URL: https:/ /volsu.ru/Abitur/bachelor/prikazy-o-zachislenii-v2019-godu.php (accessed 2 January 2020).

16. Lebedeva M.M., ed. Publichnaya diplomatiya: Teoriya i praktika: nauch. izd. [Public Diplomacy: Theory and Practice. Scientific Publication]. Moscow, Aspect Press Publ., 2017. 272 p.

17. Sazanova N.V. Sovetsko-amerikanskie otnosheniya $\mathrm{v}$ oblasti kultury i nauki v voennyy i poslevoennyy period [US-Soviet Relations in Cultural and Scientific Areas During and After World War II]. Vestnik Volgogradskogo gosudarstvennogo universiteta. Seriya 4, Istoriya. Regionovedenie. Mezhdunarodnye otnosheniya [Science Journal of Volgograd State University. History. Area Studies. International Relations], 2013, no. 1 (23),pp. 69-74. DOI: http://dx.doi.org/10.15688/ jvolsu4.2013.1.10.

18. Mukhametshin F.M., ed. Sovremennaya obshchestvennaya diplomatiya: rossiyskoe izmerenie [Modern Public Diplomacy: Russian Dimension]. Moscow, Belyy gorod Publ., 2011. 240 p.

19. Sorokina D.A. Osnovnye etapy razvitiya publichnoy diplomatii v Rossii [The Main Stages in the Development of Russian Public Diplomacy]. Vlast, 2016, no. 4, pp. 132-137.

20. Stoletov O.V., Chikharev I.A. Universitety kak subyekty publichnoy diplomatii [Universities as Subjects of Public Diplomacy]. Geopoliticheskiy zhurnal [Geopolitical Magazine], 2013, no. 2, pp. 65-78.

21. Torkunov A.V. Obrazovanie kak instrument «myagkoy sily» vo vneshney politike Rossii [Education as an Instrument of "Soft Power" in Russian Foreign Policy]. Vestnik MGIMO (U) [MGIMO Review of International Relations], 2012, no. 4, pp. 86-89.
22. Fominykh A.E. Rossiyskie universitety na obrazovatelnykh rynkakh Tsentralnoy Azii: publichnaya diplomatiya, sotrudnichestvo i konkurentsiya [Russian Universities in the Educational Markets of Central Asia: Public Diplomacy, Cooperation and Competition]. Vestnik Tomskogo gosudarstvennogo universiteta. Istoriya [Tomsk State University Journal. History], 2014, no. 6 (32), pp. 28-31.

23. Tsentr obshchestvennoy diplomatii. Volgogradskiy gosudarstvennyy universitet [Center for Public Diplomacy. Volgograd State University]. URL: http://cod.volsu.ru/ (accessed 3 January 2020).

24. Shershnev I.L. Kontseptualnye osnovy proekta Federalnogo Zakona «Ob obshchestvennoy diplomatii Rossiyskoy Federatsii» [Conceptual Basis of the Draft Federal Law "On Public Diplomacy of the Russian Federation"]. Vestnik MGLU [Vestnik of Moscow State Linguistic University], 2010, iss. 25 (604), pp. 164-170.

25. Defrance C., Pfeil U., eds. Le traité de l'Élysée et les relations franco-allemandes 1945-1963-2003. Paris, CNRS éditions, 2005. 268 p.

26. Malone G. Political Advocacy and Cultural Communications: Organising the Nation's Public Diplomacy. Lanheim, UniversityofAmerica, 1988. 178 p.

27. Nye J. Soft Power and Higher Education. 2004. URL: https://www.academia.edu/10134073/ Soft_power_university (accessed 24 December 2019).

28. Melissem J., ed. The New Public Diplomacy. Soft Power in International Relations. London, Palgrave Macmillan, 2005. 222 p.

29. Traité de l' Élysée (22 janvier 1963). Le couple franco-allemand. URL: https://www.franceallemagne.fr/Traite-de-1-Elysee-22-janvier-1963.html (accessed 12 December 2019).

30. Tuch H.N. Communication with the World. US Public Diplomacy Overseas. Washington, Georgetown University Press, 1990. 224 p.

\section{Information About the Authors}

Ekaterina V. Arkhipova, Candidate of Sciences (History), Associate Professor, Department of International Relations, Political Science and Area Studies, Volgograd State University, Prosp. Universitetsky, 100, 400062 Volgograd, Russian Federation, arkhipovakv@volsu.ru, https://orcid.org/0000-0003-1891-5586

Elena F. Parubochaya, Candidate of Sciences (History), Associate Professor, Department of International Relations, Political Science and Area Studies, Volgograd State University, Prosp. Universitetsky, 100, 400062 Volgograd, Russian Federation, parubochaya@volsu.ru, https://orcid.org/0000-0002-2115-6595

Constantinos Koliopoulos, Ph.D. (Strategic Studies), Associate Professor in International Politics and Strategic Studies, Department of International, European and Regional Studies, Panteion University of Social and Political Sciences, Prosp. Syggrou, 136, 17671 Athens, Greece, drmodel44@hotmail.com, https://orcid.org/0000-0002-9954-1274 


\section{УНИВЕРСИТЕТЫ КАК ФАКТОР МЕЖДУНАРОДНОГО СОТРУДНИЧЕСТВА \\ Информация об авторах}

Екатерина Владимировна Архипова, кандидат исторических наук, доцент кафедры международных отношений, политологии и регионоведения, Волгоградский государственный университет, просп. Университетский, 100, 400062 г. Волгоград, Российская Федерация, arkhipovakv@volsu.ru, https://orcid.org/0000-0003-1891-5586

Елена Федоровна Парубочая, кандидат исторических наук, доцент, кафедра международных отношений, политологии и регионоведения, Волгоградский государственный университет, просп. Университетский, 100, 400062 г. Волгоград, Российская Федерация, parubochaya@volsu.ru, https://orcid.org/0000-0002-2115-6595

Константинос Колиопулос, Ph.D. по стратегическим исследованиям, доцент по международной политике и стратегическим исследованиям, департамент международных, европейских и региональных исследований, Университет «Пантеон» социальных и политических наук, просп. Сигpay, 136, 17671 г. Афины, Греция, drmodel44@hotmail.com, https://orcid.org/0000-0002-9954-1274 